\title{
Antiproliferative Effects of Ferula assa-foetida's Extract on PC12 and MCF7 Cancer Cells
}

\author{
Mina Abroudi ${ }^{1}$, Amir Ganji Fard ${ }^{1}$, Ghazaleh Dadashizadeh ${ }^{1}$, Omid Gholami, ${ }^{1,}$, \\ Davood Mahdian ${ }^{1,2, *}$ \\ ${ }^{1}$ Cellular and Molecular Research Center, Sabzevar University of Medical Sciences, Sabzevar, Iran \\ ${ }^{2}$ Department of Pharmacology, School of Medicine, Sabzevar University of Medical Sciences, Sabzevar, Iran
}

\author{
Email address: \\ Mahdiand64@gmail.com (D. Mahdian) \\ ${ }^{*}$ Corresponding author
}

\section{To cite this article:}

Mina Abroudi, Amir Ganji Fard, Ghazaleh Dadashizadeh, Omid Gholami, Davood Mahdian. Antiproliferative Effects of Ferula assafoetida's Extract on PC12 and MCF7 Cancer Cells. International Journal of Biomedical Engineering and Clinical Science.

Vol. 6, No. 3, 2020, pp. 60-67. doi: 10.11648/j.ijbecs.20200603.12

Received: August 3, 2020; Accepted: August 17, 2020; Published: October 30, 2020

\begin{abstract}
Background: Ferula assa-foetida is a herbaceous plant of the Umbelliferae family having a broad spectrum of biological activities such as antiseptic, antibacterial, anti-inflammation, and, anti-tumor activity against a wide range of cancers Among these features, antitumor activity has become more important in recent years and it still demands more investigations to address the underlying mechanisms. Purpose: This current study was conducted to evaluate the anti-proliferative effect of Ferula assa-foetida on PC12 and MCF7 cells as well as examining its mechanisms. Materials and Methods: Cells were cultured in DMEM medium with $10 \%$ fetal bovine serum, 100 units $/ \mathrm{ml}$ penicillin, and $100 \mu \mathrm{g} / \mathrm{ml}$ streptomycin. Cells incubated with different concentrations of the ethanolic extract of Ferula assa-foetida. Notably, cytotoxicity and apoptosis assay were measured by MTT and PI staining, respectively. Results: The MTT results showed that the ethanolic extract of Ferula assa-foetida in concentrations of $10,7,5$, and $2.5 \mu \mathrm{M}$ on both PC12 and MCF7 cells had a significant effect in cell viability and apoptosis induction in comparison to control group. Conclusion: In this study, it was determined that Ferula assafetida through the induction of apoptosis prevented the growth of PC12 and MCF7 cells and made a reduction in cell viability with different concentrations in a time- and dose-dependent manner. However, more studies are needed to reveal the mechanisms of Ferula assa-foetida's extract in apoptosis induction.
\end{abstract}

Keywords: Ferula assa-foetida, Apoptosis, Cytotoxicity, Cancer, MCF7, PC12

\section{Introduction}

Cancer is one of the most important public health problems worldwide, which is the second leading cause of death in the world [1]. In industrialized countries, breast cancer is the most common type of cancer among women [2], and common therapies are including radiotherapy and chemotherapy that stop cell cycle or induce cell death through apoptotic or non-apoptotic mechanisms such as necrosis, mitotic catastrophe, and autophagy [3-5]. These therapies have some disadvantages, including damage to healthy cells [6]. Despite advances in the development of novel drugs, cancer treatment still demands precise and specific drugs in order to reduce the side effects of chemotherapeutics. To date, various natural compounds have shown promising insights on the treatment and prevention of cancer having the advantage to lower the side effects. Natural plant products can play an important role in cancer treatment through blocking tumor and inducing apoptosis [7].

Herbal plants are important sources of bioactive compounds which have shown promising insights in the treatment of various cancers [8]. The advantages of traditional herbs are their lower toxicity, cost and side effects $[9,10]$. The efficacy of these chemotherapy drugs is largely related to its antioxidant potential which reduces or inhibits damages of free radicals to DNA, lipids, and proteins as macromolecules [11] likewise antitumor drugs which their mechanism relies on the production of free radicals [12]. 
However, herbal plants such as Ferula assa-foetida has shown apoptosis induction by modulating the expression of genes related to this cellular process [8].

Ferula assa-foetida is found as a natural plant in the central region of Iran. The stems and roots of this plant and other species have clinical applications [13]. The root of this plant is extensively used in traditional medicine including the treatment of influenza [14], and also its dried extract is used in the treatment of hysteria, whooping cough, and ulcers in Afghanistan [15]. The extraction of Ferula assa-foetida is utilized as a vermifuge in China [16]. In Egypt, its dried root extract is used as an antispasmodic, analgesic, diuretic, and vermifuge [17]. In Malaysia, it is used as amenorrhea [18], and has applicable as an antiepileptic in Morocco [19]. In Saudi Arabia, the dried plant is used for whooping cough, asthma, and bronchitis [20]. It is used to treat gastrointestinal diseases by removing wind from the stomach and also treats any spasmodic disorders. It is as a nervine stimulant, digestive, and sedative agents [8, 21]. In folk medicine, the roots of this plant are used as perceived anthelmintic, anticarcinogenesis, anti-HIV, antimicrobial, antirheumatic, antispasmodic, diuretic, and emmenagogue [14]. The pharmacological and biological studies of Ferula assa-foetida have also reported a large number of drug activities such as antioxidant [22], antileishmanial [23], anticonvulsant [24], anti-diabetic [25], antispasmodic [26], hypotensive [27], and antinociceptive [28]. Recent statistics have shown that cancer rates are higher in countries such as Japan, Russia, China, and Indonesia in comparison to countries using Ferula assa-foetidathis is common [29]. In current studies, the antioxidant, antimutagenicity, and anticancer activities of this plant have been reported [21].

\section{Materials and Methods}

\subsection{Chemicals}

PC12 and MCF7 cell lines were obtained from the Pasteur Institute (Tehran, Iran). Dulbecco's phosphatebuffered saline (PBS) and 4, 5-dimethylimidazole-2-yl, 2, 5-diphenyl tetrazolium (MTT) were purchased from Sigma (St Louis, MO, USA). Glucose-high Dulbecco's modified Eagle's medium (DMEM), fetal bovine serum (FBS) and penicillin-streptomycin were purchased from Gibco (Grand Island, NY). Dimethyl sulfoxide (DMSO) was bought from Merck (Germany). Propidium iodide (PI), sodium citrate and Triton X-100 were purchased from Sigma (St Louis, MO, USA).

\subsection{Cell Culture}

Cells were cultured in DMEM with $10 \%$ fetal bovine serum, 100 units $/ \mathrm{ml}$ penicillin and $100 \mu \mathrm{g} / \mathrm{ml}$ streptomycin. Cells were plated and incubated with various concentrations of Ferula assa-foetida for 24, 48 and $72 \mathrm{~h}$. For MTT assay, cells were seeded at $5000 /$ well on to $96-$ well culture plates. For each concentration and time course, a control sample which remained untreated and received the equal volume of the medium has been used. For apoptosis assessment, cells were seeded at $1 \times 10^{5} /$ well on to a 24-well plate [30]. All different treatments were carried out in triplicate.

\subsection{Drug Preparation}

The upper part of Ferula assa-foetida maintained at room temperature for 10 days. Following being dried, the powder was prepared. The dried powder was extracted by ethanol keeping at room temperature for 7 days. Interestingly, the ethanol extract was dried by evaporation. To prepare concentrations of $10,5,2.5,1.25,0.62,0.31,0.15,0.07$, and $0.03 \mu \mathrm{M}$, the dried extract was solubilized in culture medium.

\subsection{Cell Viability}

The cell viability was determined using a modified 3-(4, 5dimethylthiazol-2-yl)-2, 5-diphenyl tetrazolium (MTT) assay [30]. Briefly, PC12 and MCF7 cells were seeded at $5 \times 10^{3} /$ well in flat-bottom 96 -well culture plates and allowed to grow for 24,48 and $72 \mathrm{~h}$ following treatment with an ethanolic extract of Ferula assa-foetida at different concentrations [0.0312 up to $10 \mu \mathrm{M}]$. After the medium was removed, cells were incubated with MTT solution $(5 \mathrm{mg} / \mathrm{ml}$ in PBS) for $4 \mathrm{~h}$ and the resulting formazan was solubilized with DMSO $(100 \mu \mathrm{l})$. The absorption was measured at 570 $\mathrm{nm}(620 \mathrm{~nm}$ as a reference) using an ELISA reader. Later, IC50s were determined through Prism software. All treatments were carried out in triplicate.

\subsection{Cell Apoptosis Assay}

Based on PI staining of small DNA fragments, apoptotic cells were detected using flow cytometry. It has been reported that a sub-G1 peak reflects DNA fragmentation observed following the incubation of cells with a hypotonic phosphate-citrate buffer containing a quantitative DNAbinding dye, such as PI. Briefly, PC12 cells were seeded in a 24-well plate and treated with the concentrations of 0.26 , 2.63, and 4.69 $\mu \mathrm{M}$ of Ferula assafoetida. Also, MCF7 cells were seeded in a 24-well plate and treated with the concentrations of $0.75,1.30$, and $1.28 \mu \mathrm{M}$ of Ferula assafoetida for $24 \mathrm{~h}, 48 \mathrm{~h}$, and $72 \mathrm{~h}$, respectively. Floating and adherent cells were then harvested and incubated with $750 \mu \mathrm{l}$ of a hypotonic buffer $(50 \mathrm{mg} / \mathrm{ml}$ PI in $0.1 \%$ sodium citrate with $0.1 \%$ Triton $\mathrm{X}-100$ ) at $4{ }^{\circ} \mathrm{C}$ overnight in the dark. Finally, flow cytometry was carried out using a FACScan flow cytometer (Becton Dickinson). A total of $1 \times 10^{4}$ events were acquired with FACS, and finally, data was analyzed through flowJo-V10 software. All treatments were carried out in triplicate.

\subsection{Statistical Analysis}

All results were expressed as mean \pm SEM. The significance of difference was evaluated with ANOVA and 
Bonferroni's test. A probability level of $\mathrm{p}<0.05$ was considered statistically significant.

\section{Results}

\subsection{The Effect of Ferula Assa-foetida's Extract on Cell Cytotoxicity}

The results of the current study showed that Ferula assafoetida's extract had an antiproliferative effect against PC12 and MCF7 cells in a dose-dependent manner.

\subsubsection{The Effect of Ferula Assa-foetida's Extract on the Viability of PC12 and MCF7 Cells}

The results of the MTT assay showed that the viability of PC12 cells was reduced in time- and dose-dependent manner with higher efficiency in higher concentrations $(<5 \mu \mathrm{M})$ (Figure 1). At exposure time of $24 \mathrm{~h}$, treatment with Ferula assa-foetida in the concentrations of $2.5,5,7$, and $10 \mu \mathrm{M}$ had a significant effect on cells viability $(\mathrm{p}<0.001)$ While in exposure time of $48 \mathrm{~h}$ and $72 \mathrm{~h}$, treatment with Ferula assafoetida's extract had a significant effect on cells viability $(\mathrm{p}<0.001)$ in all concentrations. pc12-24h

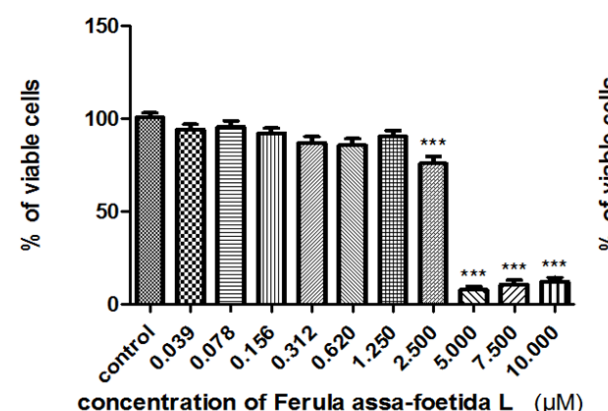

a

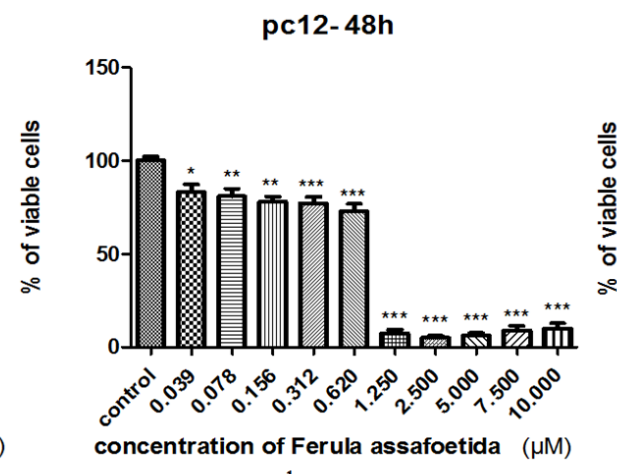

b pc12-72h

Figure 1. The effect of Ferula assa-foetida's extract on the viability of PC12 cells. PC12 cells were treated with different concentrations of Ferula assa-foetida

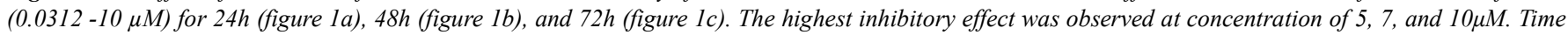
exposure of $48 \mathrm{~h}$ and $72 \mathrm{~h}$ were more effective in reducing the viability of PC12 cells (figure $1 \mathrm{~b}$ and figure $1 \mathrm{c}$ ). IC50s for $24 \mathrm{~h}$, $48 \mathrm{~h}$, and $72 \mathrm{~h} \mathrm{treatment} \mathrm{were}$ calculated, and were 2.84, 0.8, and $0.4 \mu M$, respectively. Results are expressed as Mean $\pm \operatorname{SEM}(n=3) . *_{p}^{*}<0.05, * * p<0.01, * * * p<0.001$.

\subsubsection{The Effect of Ferula Assa-foetida's Extract on the Viability of MCF7 Cells}

The results showed that the extract of Ferula assa-foetida reduced cell viability in a time- and dose-dependent manner (Figure 2). At an exposure time of $24 \mathrm{~h}$ and $48 \mathrm{~h}, \mathrm{MCF} 7$ cells

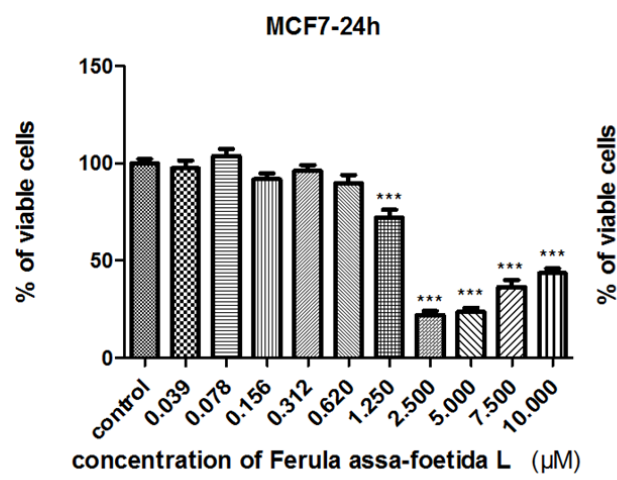

a treated by Ferula assa-foetida's extract had a significant effect on cell viability $(\mathrm{p}<0.001)$ in the concentrations of 10 , $7,5,2.5$, and $1.25 \mu \mathrm{M}$. With an exposure time of $72 \mathrm{~h}$, in all doses, Ferula assa-foetida's extract had a significant effect on cells viability $(\mathrm{p}<0.001)$.
MCF7- 48h

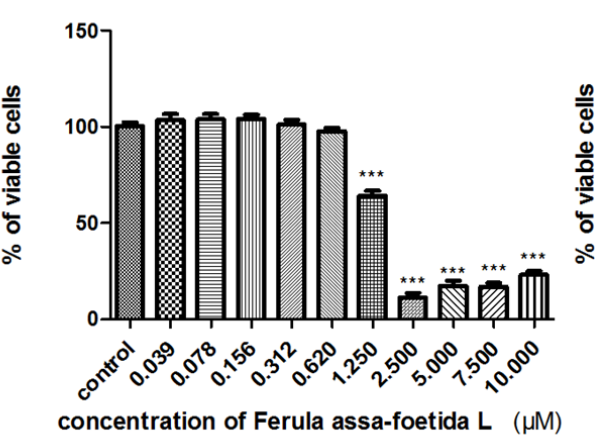

b

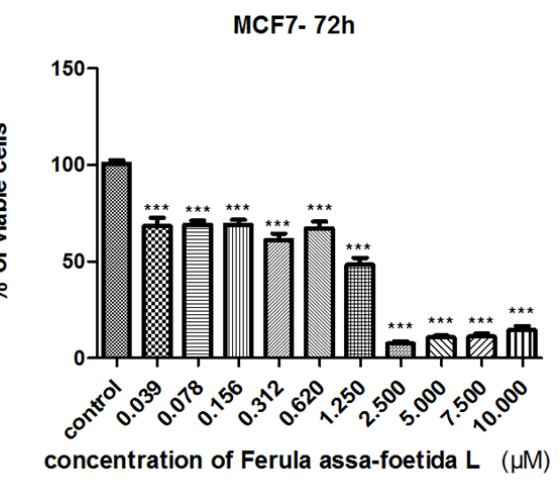

c

Figure 2. The effect of Ferula assa-foetida's extract on the viability of MCF7 cells. MCF7 cells were treated with different concentrations of Ferula assafoetida (0.0312-10 $\mu \mathrm{M}$ ) for $24 \mathrm{~h}$ (figure 2a), 48h (figure 2b), and $72 \mathrm{~h}$ (figure 2c). The highest inhibitory effect was observed at concentration of 2.5, 5, 7, 10 $\mu \mathrm{M}$ concentrations. Time exposure of $72 \mathrm{~h}$ was more effective in reducing the viability of MCF7 cells (figure $2 \mathrm{c}$ ). IC50s for $24 \mathrm{~h}$, $48 \mathrm{~h}$, and $72 \mathrm{~h}$ treatment were calculated, and were 1.30, 1.284, $0.753 \mu M$, respectively. Results are expressed as Mean $\pm \operatorname{SEM}(n=3) . *_{* *}^{*}<0.0001$.

\subsection{Apoptosis Induction Using PI Staining}

\subsubsection{The Assessment of Apoptotic PC12 Cells Using PI Staining}

The toxic effects of Ferula assa-foetida's extract were observed on PC12 cells. IC50 concentrations evaluated as
$2.84,0.8$, and $0.4 \mu \mathrm{M}$ for time exposure of 24,48 and $72 \mathrm{~h}$, respectively. The number of apoptotic cells was calculated using PI staining. According to Figure 3, the sub-G1 peak analysis demonstrated the amount of apoptosis induction in PC12 cells treated by Ferula assafoetida's extract. Figure 4. 

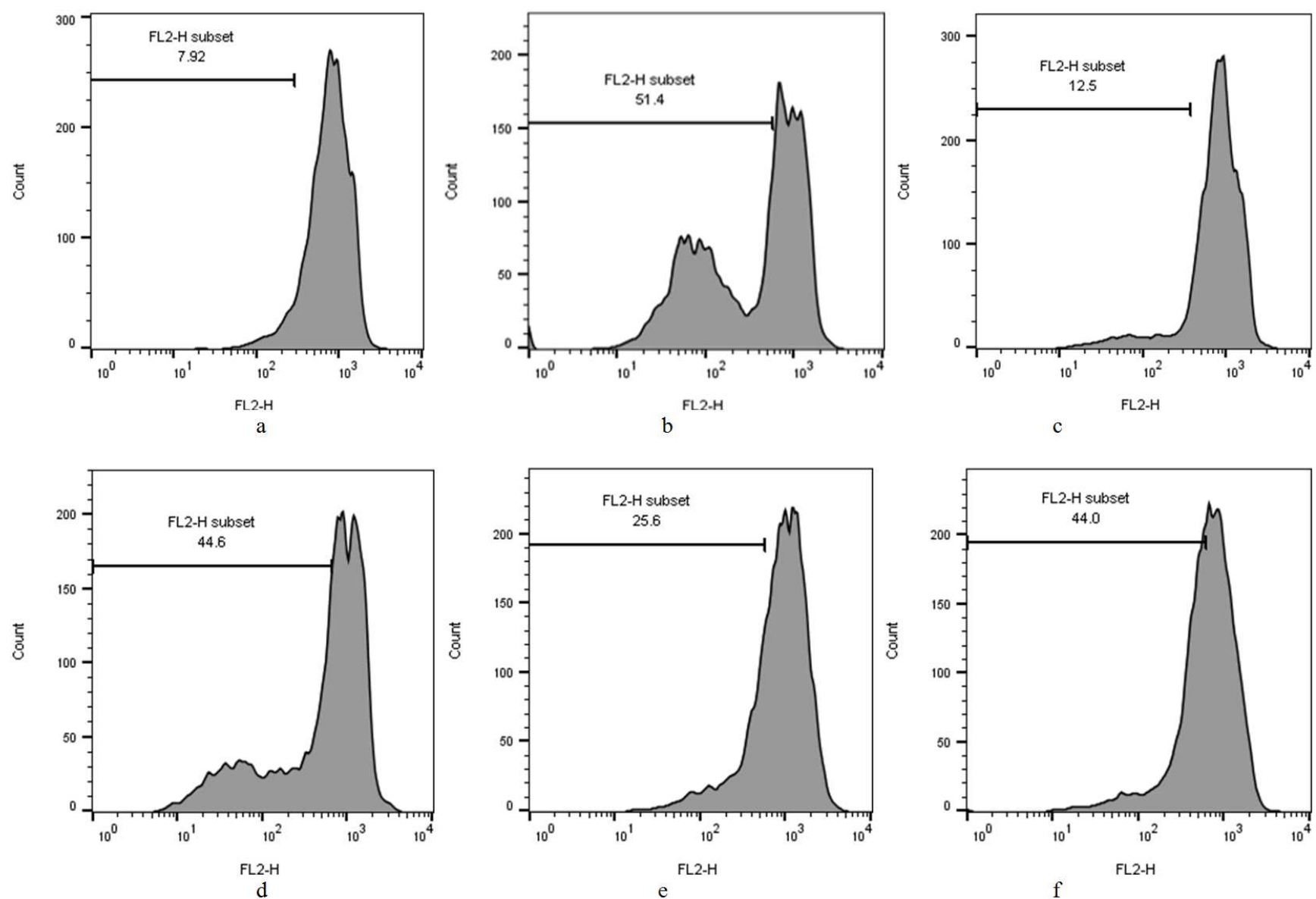

Figure 1. Ethanolic extract of Ferula assa-foetida induced apoptosis on PC12 cells. Figure 3a, flow cytometry histogram of PI-staining on PC12 cells in the control group for 24h. figure 3b, flow cytometry histogram of PI-staining on PC12 cells that were treated with a concentration of $2.84 \mu M$ of Ferula assafoetida's extract for $24 \mathrm{~h}$. figure 3c, flow cytometry histogram of PI-staining on PC12 cells in the control group for 48h. figure 3d, flow cytometry histogram of PI-staining on PC12 cells that were treated with a concentration of $0.8 \mu \mathrm{M}$ of Ferula assafoetida's extract for $48 \mathrm{~h}$. figure $3 e$, flow cytometry histogram of PI-staining on PC12 cells in the control group for $72 \mathrm{~h}$. figure $3 \mathrm{f}$, flow cytometry histogram of PI-staining on PC12 cells that were treated with a concentration of $0.4 \mu \mathrm{M}$ of Ferula assa-foetida's extract for $72 \mathrm{~h}$.

PC12-24h

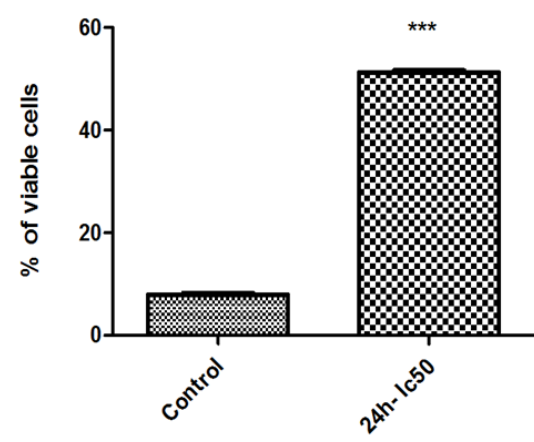

concentration of Ferula assa-foetida $(\mu \mathrm{M})$

a
PC12-48h

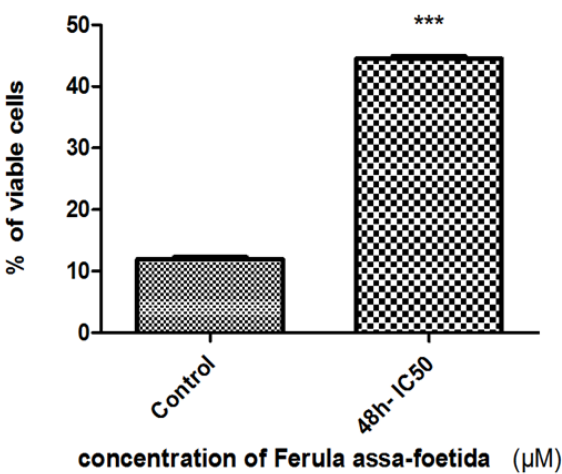

b
PC12-72h

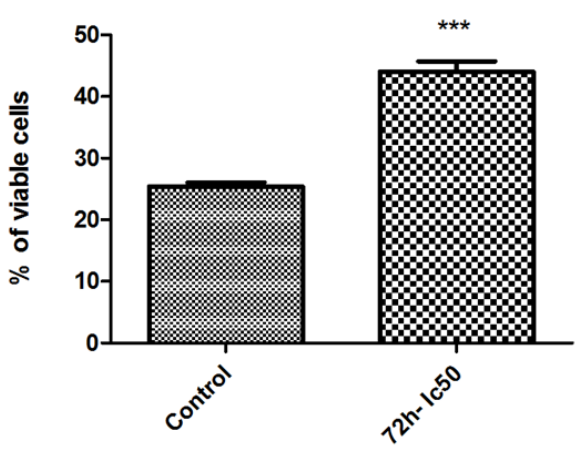

concentration of Ferula assa-foetida $(\mu \mathrm{M})$ c

Figure 4. PI-staining of apoptotic PC12 cells. Figure 4a, PC12 cells were treated with concentration of $2.84 \mu$ M of Ferula assa-foetida's extract for $24 h$. Figure $4 b, P C 12$ cells were treated with concentration of $0.8 \mu \mathrm{M}$ of Ferula assafoetida's extract for $48 \mathrm{~h}$. Figure $4 c$, PC12 cells were treated with concentration of $0.4 \mu \mathrm{M}$ of Ferula assafoetida's extract for $72 \mathrm{~h}$. It should be noted that these concentrations were IC50s for $24 h, 48 h$ and $72 h, * * * p<0.0001$.

\subsubsection{PI Staining on MCF7 Cells}

The toxic effects of Ferula assa-foetida's extract were observed on MCF7 cells. IC50 concentrations evaluated as $1.30,1.284,0.753 \mu \mathrm{M}$ for time exposure of 24,48 and $72 \mathrm{~h}$, respectively. The number of apoptotic cells was evaluated using PI staining. According to Figure 5, the sub-G1 peak analysis demonstrated the amount of apoptosis induction in MCF7 cells that were treated with Ferula assa-foetida's extract. Figure 6. 


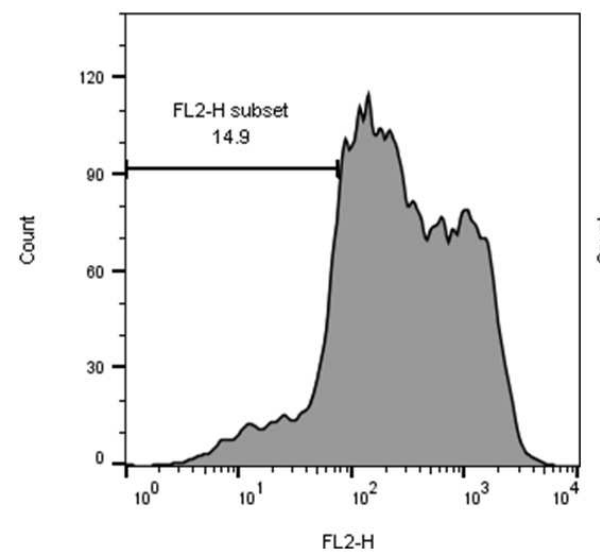

a

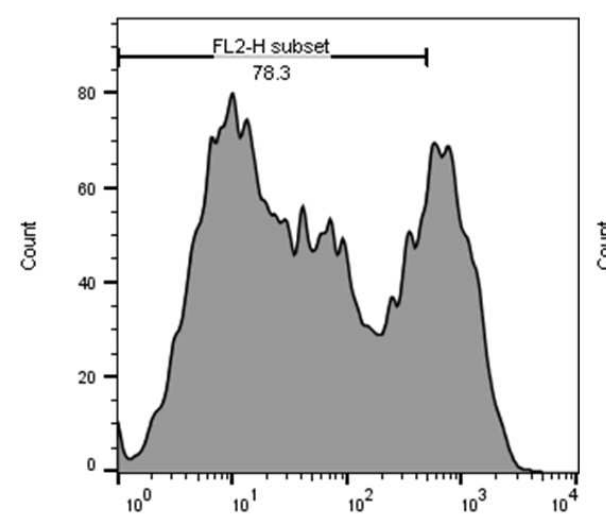

d

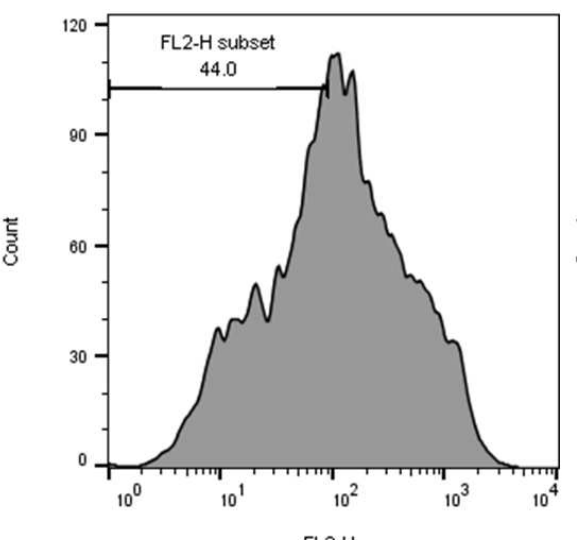

b

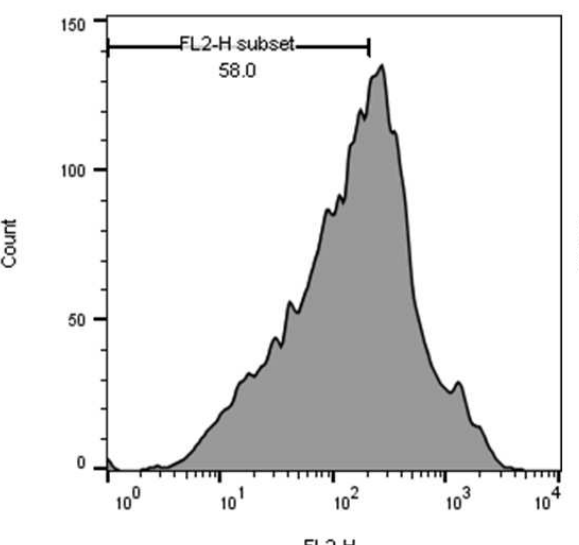

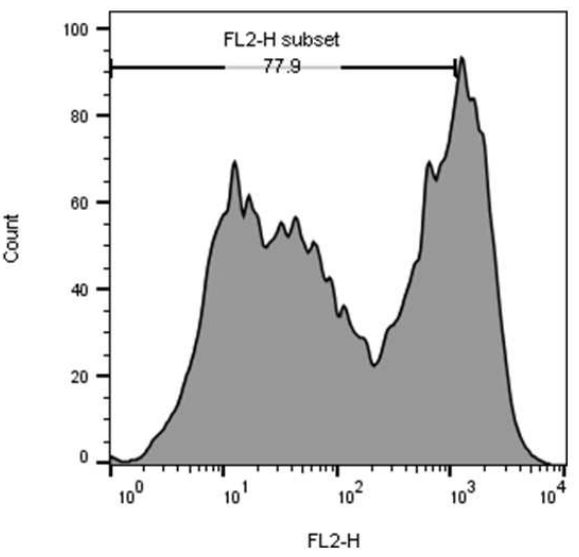

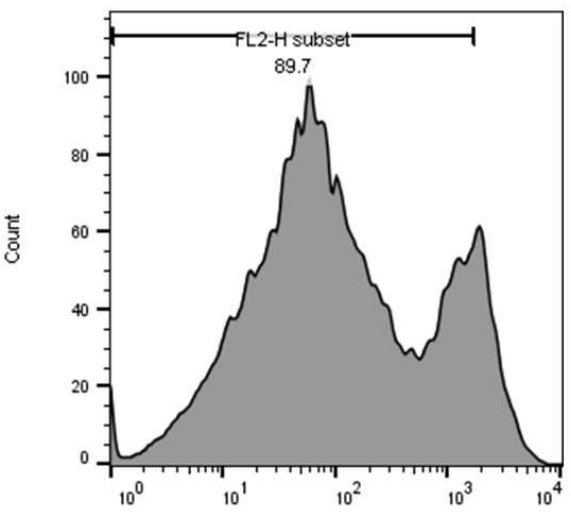

f

Figure 5. Ethanolic extract of Ferula assa-foetida induced apoptosis on MCF7 cells. figure 5a, flow cytometry histogram of PI-staining on MCF7 cells in the control group for 24h. figure 5b, flow cytometry histogram of PI-staining on MCF7 cells that were treated with a concentration of $1.30 \mu M$ of Ferula assafoetida's extract for $24 \mathrm{~h}$. figure 5c, flow cytometry histogram of PI-staining on MCF7 cells in the control group for $48 \mathrm{~h}$. figure $5 \mathrm{~d}$, flow cytometry histogram of PI-staining on MCF7 cells that were treated with a concentration of $1.284 \mu \mathrm{M}$ of Ferula assa-foetida's extract for 48 h. figure 5e, flow cytometry histogram of PI-staining on MCF7 cells in the control group for 72h. figure 5f, flow cytometry histogram of PI-staining on MCF7 cells that were treated with a concentration of $0.753 \mu \mathrm{M}$ of Ferula assa-foetida's extract for $72 \mathrm{~h}$.

MCF7- 24h

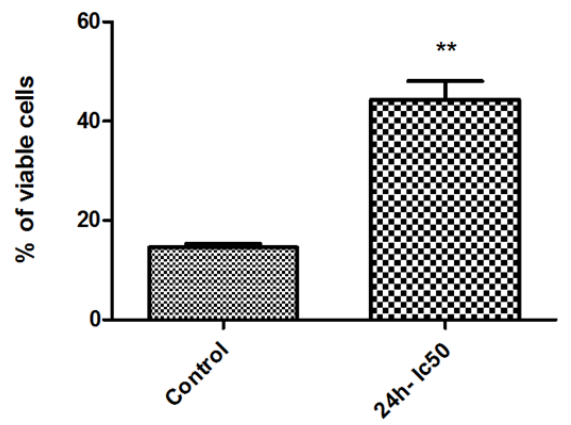

concentration of Ferula assa-foetida $(\mu \mathrm{M})$

a
MCF7- 48h

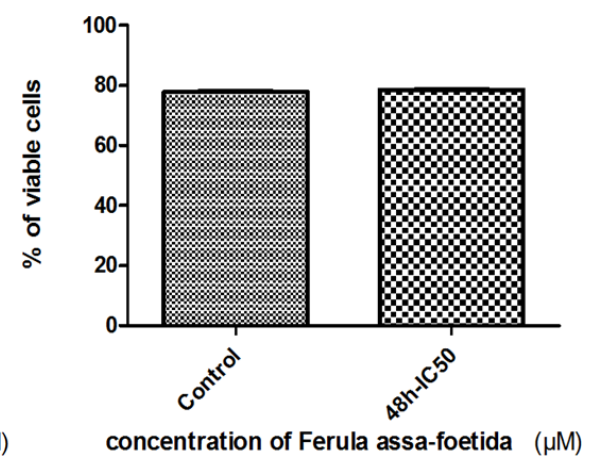

b

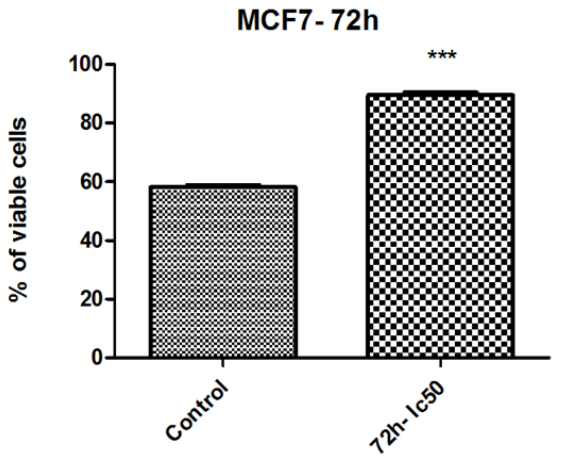

concentration of Ferula assa-foetida $(\mu \mathrm{M})$

Figure 6. PI-staining of apoptotic MCF7 cells. Figure 6a, MCF7 cells were treated with concentration of $1.30 \mu M$ of Ferula assa-foetida's extract for 24 h. Figure 6b, MCF7 cells were treated with concentration of $1.28 \mu \mathrm{M}$ of Ferula assa-foetida's extract for $48 \mathrm{~h}$. Figure 6c, MCF7 cells were treated with concentration of $0.75 \mu \mathrm{M}$ of Ferula assa-foetida's extract for $72 \mathrm{~h}$. It should be noted that these concentrations were IC50 for $24 \mathrm{~h}$, $48 \mathrm{~h}$ and $72 \mathrm{~h}$, **P<0.01, $* * * p<0.0001$.

\section{Discussion}

Our aim was to investigate the anti-proliferative effect of Ferula assa-foetida on MCF7 and PC12 cancer cells. In the current study, it was concluded that Ferula assa-foetida's extract strongly reduced the viability of PC12 and MCF7 cells in a dose- and time-dependent manner. The results of apoptotic induction showed Ferula assa-foetida's extract 
causes DNA fragmentation in MCF7 and PC12 cells.

The results of MTT assay on MCF7 and PC12 cell demonstrated Ferula assa-foetida had an inhibitory effect. Based on previous results, it seems that this inhibitory effect results from apoptosis initiation by Ferula assa-foetida's extract. Gene expression analysis on normal fibroblast has revealed Ferula assa-foetida's extract at high concentrations reduces Bcl-2 while upregulates the expression of Bax and Caspase-3 [31]. Our data also partially reflected the matter of concentration, as we observed a higher inhibitory effect at higher concentrations of Ferula assa-foetida's extract on MCF7 and PC12 cells which may be due to hormesis [32]. In this regard, our data also showed a sub-G1 peak by flow cytometry and PI staining indicated DNA fragmentation following the initiation of apoptosis. It could be concluded that Ferula assa-foetida's extract exerted its antiproliferative effect on cancer cells through apoptosis initiation.

It was shown that lower concentrations of Oleo-gum resin from Ferula assa-foetida attenuated cellular senescence in normal human dermal fibroblasts while higher concentrations associated with the apoptosis initiation [31]. Also, Ferula assa-foetida extract increased the viability of cerebellar granule neurons of rats in lower concentrations [33].

Ferula assa-foetida has been shown to be one of the main components of the umbelliprenin family that treats asthma through the inhibition of lipoxygenase [34], and also Ferula assa-foetida is used in cancer prevention [35].

It has been shown that Ferula assa-foetida can reduce the effect of environmental mutagens in food [36]. It is demonstrated that umbelliprenin has a significant role in cancer chemotherapy [37, 38]. Previously, it was suggested that this antitumor activity is the blockage of the enzyme 5lipoxygenase [27]. Also, the hormesis phenomenon of umbelliprenin has been observed on Jurkat cells [32]. Since Ferula assa-foetida is a member of the umbelliprenin family, it seems that the effect of Ferula assa-foetida is following hormesis too [32] as our data demonstrated that higher concentrations had higher antitumor activity.

The ability to induce apoptosis instead of necrosis is considered as a key feature of potential anti-tumor medications. Apoptosis induction has been used for the prevention and treatment of cancer. Bcl-2 Proteins are a key factor in the regulation of apoptosis [39]. Bax and Bcl-2 proteins affect the permeability of the mitochondrial membrane. The onset of apoptotic signaling cascades depends on the balance between proapoptotic and antiapoptotic proteins from the Bcl-2 family [40]. The permeability of mitochondrial membrane caused soluble molecules to release from mitochondrial outer space to the cytosol, one of these molecules is Smac/DIABLO which activates the caspase cascade in the cytosol [41]. Caspase activation causes cytochrome $\mathrm{C}$ to release which resulted in the inactivation of an apoptosis-inhibiting protein family [42]. The p53, tumor suppressor protein, plays an important role in the onset of apoptosis by intrinsic and extrinsic stresses. Notably, p53 defect leads to failure in cancer chemotherapy [43]. Apoptosis occurs at the end of the phase
G1 and G2 with activation of p53 [44]. In the present study, the effect of Ferula assa-foetida on the induction of apoptosis was evaluated using flow cytometry. Results showed that Ferula assa-foetida could induce apoptosis on MCF7 and PC12 cells. In previous studies, treated with Ferula assa-foetida, it has been shown that the Bax expression was increased while $B c l-2$ expression decreased, and by inhibiting the cell cycle and activating the mitochondrial pathway, apoptosis was initiated [45]. However, the initiation of apoptosis is similar to what occurred by inducing umbelliprenin's extract on Jurkat cells [32].

To summarize, many reports have illustrated various effects of Ferula assa-foetida and its derivatives. Due to hormesis, our results indicated that Ferula assa-foetida's extract at high concentrations inhibited the proliferation of MCF7 and PC12 cells. Also, apoptosis analysis demonstrated that treatment by Ferula assa-foetida induced apoptosis in cancer cells. Ferula assa-foetida's extract is a potential herbal product with apoptotic effect even though more investigations are needed to determine the underlying mechanisms.

\section{Conclusion}

The present study showed that Ferula assa-foetida is a strong inducer of apoptosis that inhibits the growth of PC12 and MCF7 cells so that with the onset of apoptosis it prevents cancer. However, more studies are needed to prove the mechanism of the Ferula assa-foetida extract in inducing apoptosis.

\section{Funding}

This study was funded by Vice Chancellor for Research, Sabzevar University of Medical Sciences, Sabzevar, Iran [grant number 96121], funded this study.

\section{Ethical Approval}

This article does not contain any studies with human participants or animals performed by any of the authors.

\section{Conflict of Interest}

All authors declare they have no conflict of interest.

\section{References}

[1] Jemal A, Murray T, Ward E, Samuels A, Tiwari RC, Ghafoor A, et al. Cancer statistics, 2005. CA: a cancer journal for clinicians. 2005; 55 (1): 10-30.

[2] Kamangar F, Dores GM, Anderson WF. Patterns of cancer incidence, mortality, and prevalence across five continents: defining priorities to reduce cancer disparities in different geographic regions of the world. Journal of clinical oncology. 2006; 24 (14): 2137-50. 
[3] Ghobrial IM, Witzig TE, Adjei AA. Targeting apoptosis pathways in cancer therapy. CA: a cancer journal for clinicians. 2005; 55 (3): 178-94.

[4] Brown JM, Attardi LD. The role of apoptosis in cancer development and treatment response. Nature reviews cancer. 2005; 5 (3): 231.

[5] Okada H, Mak TW. Pathways of apoptotic and non-apoptotic death in tumour cells. Nature Reviews Cancer. 2004; 4 (8): 592.

[6] Baskar R, Lee KA, Yeo R, Yeoh K-W. Cancer and radiation therapy: current advances and future directions. International journal of medical sciences. 2012; 9 (3): 193.

[7] Lee J-C, Kim J, Jang Y-S. Ethanol-eluted extract of Rhus verniciflua stokes inhibits cell growth and induces apoptosis in human lymphoma cells. Journal of biochemistry and molecular biology. 2003; 36 (4): 337-43 .

[8] Mahendra P, Bisht S. Ferula asafoetida: Traditional uses and pharmacological activity. Pharmacognosy reviews. 2012; 6 (12): 141 .

[9] Balunas MJ, Kinghorn AD. Drug discovery from medicinal plants. Life sciences. 2005; 78 (5): 431-41.

[10] Gao Y, Su Y, Qu L, Xu S, Meng L, Cai S-Q, et al. Mitochondrial apoptosis contributes to the anti-cancer effect of Smilax glabra Roxb. Toxicology letters. 2011; 207 (2): 112-20.

[11] Galati G, O'brien PJ. Potential toxicity of flavonoids and other dietary phenolics: significance for their chemopreventive and anticancer properties. Free Radical Biology and Medicine. 2004; 37 (3): 287-303.

[12] Yokoyama C, Sueyoshi Y, Ema M, Mori Y, Takaishi K, Hisatomi H. Induction of oxidative stress by anticancer drugs in the presence and absence of cells. Oncology letters. 2017; 14 (5): 6066-70.

[13] Bagheri SM, Sahebkar A, Gohari AR, Saeidnia S, Malmir M, Iranshahi M. Evaluation of cytotoxicity and anticonvulsant activity of some Iranian medicinal Ferula species. Pharmaceutical biology. 2010; 48 (3): 242-6.

[14] Lee C-L, Chiang L-C, Cheng L-H, Liaw C-C, Abd El-Razek $\mathrm{MH}$, Chang F-R, et al. Influenza A (H1N1) antiviral and cytotoxic agents from Ferula assa-foetida. Journal of natural products. 2009; 72 (9): 1568-72.

[15] Mahran G, El Alfy T, Ansari S. A phytochemical study of volatile oil of Afghanian Asafoetida. Bull Fac Pharm Cairo Univ. 1973; 12 (2): 101-7.

[16] Duke JA, Ayensu ES. Medicinal Plants of China. 2 Vols. 705 S., 1300 Strichzeichnungen. Reference Publ, Inc Algonac Michigan. 1985.

[17] Buddrus J, Bauer H, Abu-Mustafa E, Khattab A, Mishaal S, El-Khrisy E, et al. Foetidin, a sesquiterpenoid coumarin from Ferula assa-foetida. Phytochemistry. 1985; 24 (4): 869-70.

[18] Gimlette JD. A Dictionary of Malayan Medicine. A Dictionary of Malayan Medicine. 1939.

[19] Bellakhdar J, Claisse R, Fleurentin J, Younos C. Repertory of standard herbal drugs in the Moroccan pharmacopoea. Journal of ethnopharmacology. 1991; 35 (2): 123-43.

[20] Seabrook W. Adventures in Arabia Among the Bedouins: Harcourt, Brace; 1927.
[21] Iranshahy M, Iranshahi M. Traditional uses, phytochemistry and pharmacology of asafoetida (Ferula assa-foetida oleogum-resin) - A review. Journal of ethnopharmacology. 2011; 134 (1): $1-10$

[22] Bagheri SM, Hedesh ST, Mirjalili A, Dashti-r MH. Evaluation of anti-inflammatory and some possible mechanisms of antinociceptive effect of Ferula assa foetida oleo gum resin. Journal of evidence-based complementary \& alternative medicine. 2016; 21 (4): 271-6.

[23] Bafghi AF, Bagheri SM, Hejazian SH. Antileishmanial activity of Ferula assa-foetida oleo gum resin against Leishmania major: An in vitro study. Journal of Ayurveda and integrative medicine. 2014; 5 (4): 223.

[24] Bagheri SM, Rezvani ME, Vahidi AR, Esmaili M. Anticonvulsant effect of Ferula assa-foetida oleo gum resin on chemical and amygdala-kindled rats. North American journal of medical sciences. 2014; 6 (8): 408.

[25] Azizian H, Ebrahim Rezvani M, Esmaeilidehaj M, Bagheri SM. Anti-obesity, fat lowering and liver steatosis protective effects of Ferula asafoetida gum in type 2 diabetic rats: possible involvement of leptin. Iranian Journal of Diabetes and Obesity. 2012; 4 (3): 120-6.

[26] Bagheri SM, Hejazian SH, Dashti-R M. The relaxant effect of seed fs essential oil and oleo-gum-resin of Ferula assa-foetida on isolated rat's ileum. Annals of medical and health sciences research. 2014; 4 (2): 238-41.

[27] Fatehi M, Farifteh F, Fatehi-Hassanabad Z. Antispasmodic and hypotensive effects of Ferula asafoetida gum extract. Journal of ethnopharmacology. 2004; 91 (2-3): 321-4.

[28] Bagheri S, Dashti-R M, Morshedi A. Antinociceptive effect of Ferula assa-foetida oleo-gum-resin in mice. Research in pharmaceutical sciences. 2014; 9 (3): 207.

[29] Nigam U, Sachan S. Evaluation of Ferula asafoetida for its anticancerous activity in different countries. Journal of Pharmacognosy and Phytochemistry. 2013; 2 (4).

[30] Mahdian D, Shafiee-Nick R, Mousavi SH. Different effects of adenylyl cyclase activators and phosphodiesterases inhibitors on cervical cancer (HeLa) and breast cancer (MCF-7) cells proliferation. Toxicology mechanisms and methods. 2014; 24 (4): $307-14$

[31] Moghadam FH, Mesbah-Ardakani M, Nasr-Esfahani MH. Effects of Oleo Gum Resin of Ferula assa-foetida L. on Senescence in Human Dermal Fibroblasts: -Asafoetida reverses senescence in fibroblasts. Journal of pharmacopuncture. 2017; 20 (3): 213.

[32] Gholami O. Umbelliprenin Mediates Its Apoptotic Effect by Hormesis: A Commentary. Dose-Response. 2017; 15 (2): 1559325817710035 .

[33] Tayeboon GS, Tavakoli F, Hassani S, Khanavi M, Sabzevari O, Ostad SN. Effects of Cymbopogon citratus and Ferula assafoetida extracts on glutamate-induced neurotoxicity. In Vitro Cellular \& Developmental Biology-Animal. 2013; 49 (9): 706-15.

[34] Iranshahi M, Askari M, Sahebkar A, Adjipavlou-Litina D. Evaluation of antioxidant, anti-inflammatory and lipoxygenase inhibitory activities of the prenylated coumarin umbelliprenin. DARU: Journal of Pharmaceutical Sciences. 2009; 17 (2): 99-103. 
[35] Saleem M, Alam A, Sultana S. Asafoetida inhibits early events of carcinogenesis: a chemopreventive study. Life sciences. 2001; 68 (16): 1913-21.

[36] Kochhar K. Dietary spices in health and diseases: I. Indian J Physiol Pharmacol. 2008; 52 (2): 106-22.

[37] Iranshahi M, Kalategi F, Rezaee R, Shahverdi AR, Ito C, Furukawa $\mathrm{H}$, et al. Cancer chemopreventive activity of terpenoid coumarins from Ferula species. Planta medica. 2008; 74 (2): 147.

[38] Iranshahi M, Sahebkar A, Takasaki M, Konoshima T, Tokuda H. Cancer chemopreventive activity of the prenylated coumarin, umbelliprenin, in vivo. European Journal of Cancer Prevention. 2009; 18 (5): 412-5.

[39] Porichi O, Nikolaidou M-E, Apostolaki A, Tserkezoglou A, Arnogiannaki N, Kassanos D, et al. BCL-2, BAX and P53 expression profiles in endometrial carcinoma as studied by real-time PCR and immunohistochemistry. Anticancer research. 2009; 29 (10): 3977-82.

[40] Hosseinzadeh L, Behravan J, Mosaffa F, Bahrami G, Bahrami A, Karimi G. Curcumin potentiates doxorubicin-induced apoptosis in $\mathrm{H} 9 \mathrm{c} 2$ cardiac muscle cells through generation of reactive oxygen species. Food and Chemical Toxicology. 2011; 49 (5): 1102-9.
[41] Mao HL, Liu PS, Zheng JF, hai Zhang P, Zhou LG, Xin G, et al. Transfection of Smac/DIABLO sensitizes drug-resistant tumor cells to TRAIL or paclitaxel-induced apoptosis in vitro. Pharmacological research. 2007; 56 (6): 483-92.

[42] Hosseinzadeh L, Behravan J, Mosaffa F, Bahrami G, Bahrami AR, Karimi G. Effect of curcumin on doxorubicin-induced cytotoxicity in H9c2 cardiomyoblast cells. Iranian Journal of Basic Medical Sciences. 2011; 14 (1): 49-56.

[43] Lopez-Gonzalez JS, Prado-Garcia H, Aguilar-Cazares D, Molina-Guarneros JA, Morales-Fuentes J, Mandoki JJ. Apoptosis and cell cycle disturbances induced by coumarin and 7-hydroxycoumarin on human lung carcinoma cell lines. Lung cancer. 2004; 43 (3): 275-83.

[44] Shokoohinia Y, Hosseinzadeh L, Alipour M, Mostafaie A, Mohammadi-Motlagh H-R. Comparative evaluation of cytotoxic and apoptogenic effects of several coumarins on human cancer cell lines: osthole induces apoptosis in p53deficient H1299 cells. Advances in pharmacological sciences. 2014; 2014.

[45] Bamehr H, Saidijam M, Dastan D, Amini R, Pourjafar M, Najafi R. Ferula pseudalliacea induces apoptosis in human colorectal cancer HCT-116 cells via mitochondria-dependent pathway. Archives of physiology and biochemistry. 2018: 1-8. 